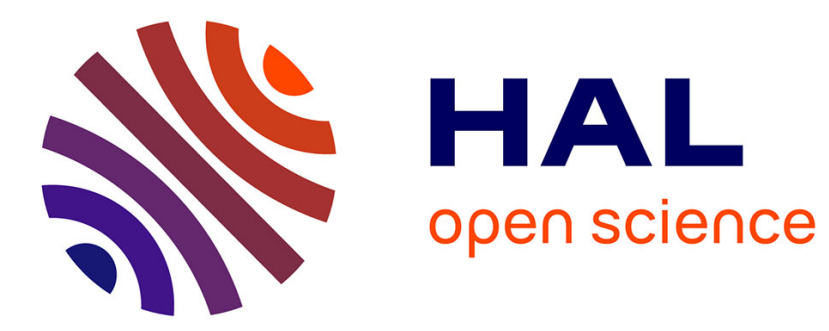

\title{
Comparaison inter-classements des revues en sociologie-démographie et en science politique \\ François Briatte
}

\section{To cite this version:}

François Briatte. Comparaison inter-classements des revues en sociologie-démographie et en science politique. Bulletin de Méthodologie Sociologique / Bulletin of Sociological Methodology, 2008, 100, pp.51-60. 10.1177/075910630810000109 . hal-00337129

\section{HAL Id: hal-00337129 \\ https://hal.science/hal-00337129}

Submitted on 6 Nov 2008

HAL is a multi-disciplinary open access archive for the deposit and dissemination of scientific research documents, whether they are published or not. The documents may come from teaching and research institutions in France or abroad, or from public or private research centers.
L'archive ouverte pluridisciplinaire HAL, est destinée au dépôt et à la diffusion de documents scientifiques de niveau recherche, publiés ou non, émanant des établissements d'enseignement et de recherche français ou étrangers, des laboratoires publics ou privés.

\section{다(1)(2)}

Distributed under a Creative Commons Attribution - ShareAlikel 4.0 International 
Graphique 1. Représentation graphique du tableau 1C

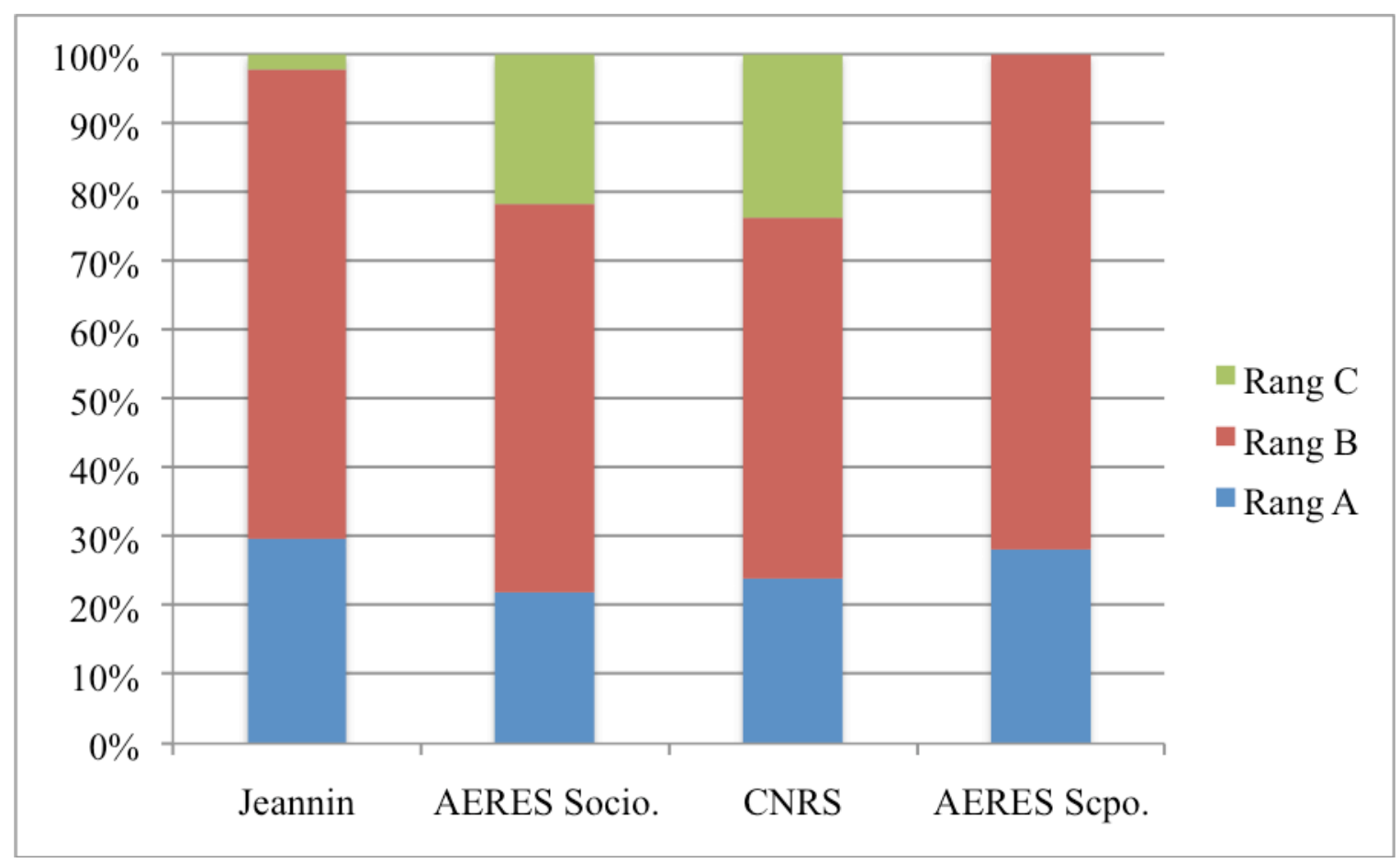

